\title{
Primary productivity and phytoplankton dynamics in a subtropical estuary: a multiple timescale approach
}

\author{
Rafael Antonio Parizzi ${ }^{1}$, Eunice Da Costa Machado ${ }^{1}$, Camila Prestes Dos Santos Tavares ${ }^{1}$, \\ Luciano Felício Fernandes ${ }^{2}$, Mauricio Garcia De Camargo ${ }^{1}$, Luiz Laureno Mafra Jr. ${ }^{1}$ \\ ${ }^{1}$ Universidade Federal do Paraná, Centro de Estudos do Mar, Cx. Postal 61, Pontal do Paraná, PR, Brasil, 83255-976. \\ E-mail: rafaelantonioparizzi@gmail.com.br \\ ${ }^{2}$ Universidade Federal do Paraná, Departamento de Botânica, Cx. Postal 19031, Curitiba, PR, Brasil, 81531-990.
}

\begin{abstract}
Summary: Temporal variability of physicochemical parameters and phytoplankton primary productivity, abundance and composition were investigated at Babitonga Bay, southern Brazil, using a hierarchical sampling design on the scales of months, weeks and days during spring 2012 and summer 2013. Only temperature, respiration rates and concentrations of dissolved oxygen and silicate exhibited significant differences in the greatest timescale (seasons: spring; summer). In contrast, most physicochemical parameters, such as salinity and the concentration of nitrogen compounds, varied mainly among weeks and days. This short-scale variability was similarly observed for the microphytoplankton abundance, ranging from 0.04 to $1.7 \times 10^{6}$ cells $\mathrm{L}^{-1}$ during a bloom of the diatom Skeletonema costatum. Two major phytoplankton assemblages were associated with high primary production rates: $>30 \mu \mathrm{m}$ centric diatoms such as Cyclotella spp. and Cymatodiscus sp., in spring; and a summer assemblage dominated by smaller, bloom-forming diatoms (S. costatum and Eucampia cornuta). Primary production ranged from 10.5 to $1793 \mathrm{mg} \mathrm{C} \mathrm{m}^{-2} \mathrm{~d}^{-1}$ and varied significantly between days and months, being associated with the photosynthetic active radiation level and weather conditions on the sampling day. Abundance of specific plankton taxa appeared controlled by trophic interactions, as revealed for the mixotrophic, toxic dinoflagellate Dinophysis acuminata complex and its prey, the ciliate Mesodinium rubrum.
\end{abstract}

Keywords: primary production; phytoplankton; physicochemical parameters; temporal variability; different time scales; Babitonga Bay; Dinophysis acuminata.

Producción primaria y dinámica del fitoplancton en un estuario subtropical: un enfoque múltiple de escalas de tiempo

Resumen: Se investigaron la variabilidad temporal de los parámetros físico-químicos y la producción primaria (PP), abundancia y composición del fitoplancton en la Bahía de Babitonga, sur de Brasil, utilizando un diseño de muestreo jerárquico en las escalas de meses, semanas y días, durante la primavera/2012 y verano/2013. Sólo la temperatura, las tasas de respiración y las concentraciones de oxígeno disuelto y silicato mostraron diferencias significativas en las escalas de tiempo mayores (estaciones: primavera; verano). En contraste, la mayoría de los parámetros fisicoquímicos, tales como la salinidad y la concentración de compuestos de nitrógeno, varió principalmente entre semana y días. Tal variabilidad de corta escala se observó de manera similar para la abundancia de microfitoplancton, oscilando desde 0,04 a $1.7 \times 10^{6}$ céls. $\mathrm{L}^{-1}$ durante una floración de la diatomea Skeletonema costatum. Se asociaron dos importantes grupos de fitoplancton con altas tasas de PP. diatomeas céntricas $>30 \mu \mathrm{m}$ como Cyclotella spp. y Cymatodiscus sp., en primavera; y un grupo de verano dominado por pequeñas diatomeas formadoras de floraciones (S. costatum y Eucampia cornuta). La PP varió de 10.5 a $1793 \mathrm{mg} \mathrm{C} \mathrm{m}^{-2} \mathrm{~d}^{-1}$ y varió significativamente entre días y meses, siendo asociada con el nivel de radiación fotosintética activa y las condiciones meteorológicas en el día de muestreo. La abundancia de taxa específicos de plancton parece controlada por interacciones tróficas, como las revelada para el dinoflagelado tóxico mixotrófico, complejo Dinophysis acuminata y su presa, el ciliado Mesodinium rubrum.

Palabras clave: producción primaria; fitoplancton; parámetros físico-químicos; variabilidad temporal; diferentes escalas de tiempo; bahía de Babitonga; Dinophysis acuminata.

Citation/Como citar este artículo: Parizzi R.A., Machado E.C., Tavares C.P.S., Fernandes L.F., De Camargo M.G., Mafra Jr. L.L. 2016. Primary productivity and phytoplankton dynamics in a subtropical estuary: a multiple timescale approach. Sci. Mar. 80(3): 291-303. doi: http://dx.doi.org/10.3989/scimar.04358.26A

Editor: F. Peters.

Received: October 19, 2015. Accepted: May 30, 2016. Published: September 28, 2016.

Copyright: (C) 2016 CSIC. This is an open-access article distributed under the terms of the Creative Commons Attribution (CC-by) Spain 3.0 License. 


\section{INTRODUCTION}

Phytoplankton primary production (PP) is one of the main sources of organic carbon sustaining the pelagic food webs in coastal ecosystems such as estuaries (Lalli and Parsons 1997, Chen and Borges 2009). Located at the interface between the continental and oceanic environments, estuaries are influenced by both and are dynamic ecosystems with high complexity and marked variability in their physicochemical characteristics, which directly affect the rates of primary productivity and the composition and abundance of phytoplankton. This variability is determined by seasonal cycles of solar irradiance, rainfall, winds and tides, which act together in different temporal and spatial scales (Jouenne et al. 2005, Abreu et al. 2010, Kimmerer et al. 2012).

The determination of the different scales of variability in environmental parameters and biological associations is an essential component in ecological studies, especially in highly dynamic and complex environments such as estuaries. Although they represent a small portion of the water masses compared with the oceans, estuaries exhibit high rates of primary production and remineralization of organic matter, and therefore play an important role in biogeochemical cycles (Chen and Borges 2009). Although many studies have focused on productivity, biodiversity and abundance of phytoplankton in estuaries, their variability and the main mechanisms operating at different temporal and spatial scales are not fully elucidated yet. Furthermore, the studies are usually restricted to monthly, bimonthly or even seasonal sampling campaigns, and few have employed approaches focusing on the variability at smaller time scales. More refined investigations have revealed a greater complexity in the temporal variation in primary productivity, composition and biomass of phytoplankton in estuaries (Fujita and Odebrecht 2007, Cloern and Jassby 2010, Kimmerer et al. 2012) than was evident in early studies. Small-scale variability may be related to weather events, such as fronts and episodes of heavy rainfall, as well as variations in the tidal level, local currents, concentration of dissolved nutrients and the rates of grazing and competition.

The identification of temporal patterns, however, is especially difficult in dynamic environments such as estuaries. This is the case of Babitonga Bay, located on the north coast of Santa Catarina State, southern Brazil. The area surrounding the estuary has high ecological, economic and social importance, already showing signs of environmental impacts generated by the strong anthropic pressure resulting from the presence of 515,000 inhabitants (IBGE 2010) and the largest industrial park of the State. The environmental issues at Babitonga Bay are mainly related to the contamination of its waters by industrial and domestic sewage from the surrounding municipalities, deforestation, overfishing, illegal occupation of mangrove and other coastal areas, and accelerated sedimentation and accumulation of pollutants due to the closure of a former connection to the sea, the Linguado Channel (IBAMA 1998). In addition, the city of San Francisco do Sul maintains an intense port activity, which requires a regular environmental monitoring of the region.

Phytoplankton biomass and composition can vary considerably throughout the year in subtropical areas such as Babitonga Bay. Notably, seasonal phytoplankton blooms and the presence of harmful speciesmainly the mixotrophic dinoflagellates belonging to the Dinophysis acuminata complex-are frequently observed in Babitonga Bay and the surrounding areas (Mafra et al. 2014). Dinophysis spp. produce lipophilic toxin that, upon accumulation in bivalve mollusks, can cause diarrhetic shellfish poisoning in human consumers (Reguera et al. 2014), and they have been recently reported in various shellfish farms of the Santa Catarina coast (Proença et al. 2007, 2011).

The main objective of this work was to investigate the variability, on different timescales (days, weeks, months and seasons), of the physicochemical parameters, the rates of respiration and PP, and the composition and abundance of the phytoplankton in Babitonga Bay, Santa Catarina State during the spring of 2012 and the summer of 2013. The approach used herein not only allowed us to assess and better distinguish the variability that occurs on a larger timescale (monthly and seasonal) from that occurring on a smaller scale (weeks and days), but also helps determine the physicochemical parameters that explain most of the variability in primary production and phytoplankton abundance on different timescales. Additionally, this multi-scale approach can be useful for defining appropriate sampling designs and strategies in order to achieve specific objectives in the study of estuarine ecosystems.

\section{MATERIALS AND METHODS}

\section{Study area}

Located on the northern coast of Santa Catarina State $\left(26^{\circ} 02^{\prime}-26^{\circ} 28^{\prime} \mathrm{S}, 48^{\circ} 28^{\prime}-48^{\circ} 50^{\prime} \mathrm{W}\right)$, Babitonga Bay (Fig. 1) is one of the main estuarine complexes of southern Brazil. It shelters the southernmost of the large mangrove formations of South America, covering nearly 6200 ha (Cremer et al. 2006, IBAMA 1998). Considered a homogeneous water body, the bay has a water surface of $134 \mathrm{~km}^{2}$, a storage volume of about 780 million $\mathrm{m}^{3}$ and a drainage basin of $1400 \mathrm{~km}^{2}$ (Denit/IME 2004). In the eastern sector it is connected to the Atlantic Ocean through a 1850-m-wide mouth.

The average depth of Babitonga Bay is around 6 $\mathrm{m}$, with a maximum of $28 \mathrm{~m}$ in the channel leading to the Port of São Francisco do Sul. The SW-NE axis of the bay (Fig. 1), called Palmital Channel, differs from other areas in that it receives the largest hydrologic contributions and is characterized as a sediment exporter (Schettini and Carvalho 1999). In contrast, the NWSE axis, known as Linguado Channel, was blocked in 1935 during the construction of a road leading to the island of São Francisco do Sul. This intervention has permanently changed its original hydrological circulation and has induced intense sedimentation within the channel since then. 


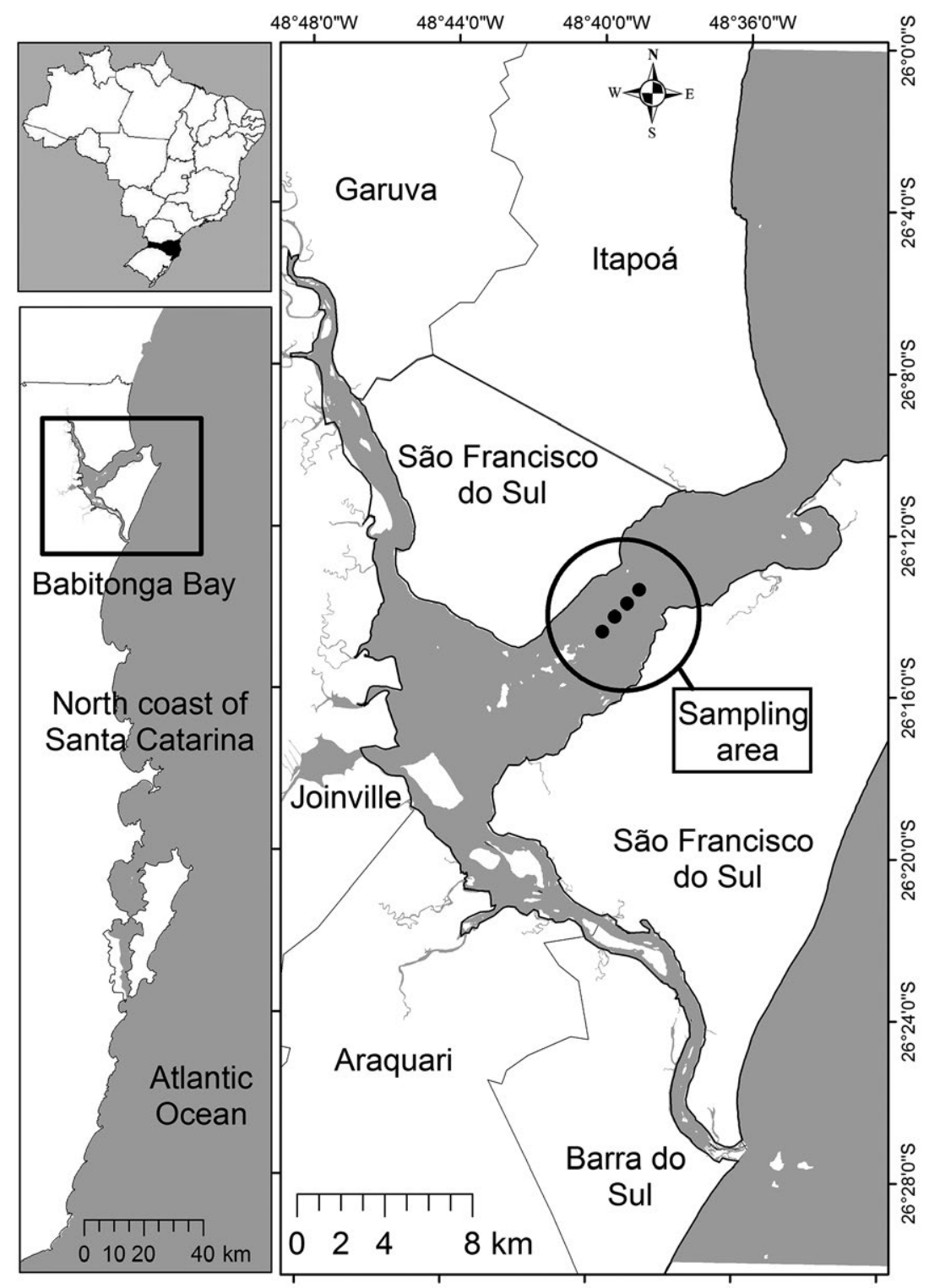

Fig. 1. - Babitonga Bay, north coast of Santa Catarina State, Brazil, showing the sampling area in the central region of the estuary.

In southern Brazil, the wave regime is controlled by the Subtropical Atlantic High pressure system and the passage of synoptic cold fronts. The most energetic waves are from the south and are generated by strong winds associated with the passage of cold fronts (Pianca et al. 2010). Prevailing winds are from the east and northeast quadrants. Tides are characterized by a system of micro-tides of mixed type with semidiurnal dominance. Unequal heights occur for consecutive high and low tides, and the maximum height is less than 2 m. In front of the Port of São Francisco do Sul, for instance, the average tidal range is $85 \mathrm{~cm}$, with maximum values of $128 \mathrm{~cm}$ (Truccolo and Schettini 1999).

The climate is characterized as humid, with a well-defined winter and summer, and the absence of a dry season. Though the area lacks a truly dry season, rainfall varies considerably throughout the year, reaching higher values in spring-summer and lower ones in autumn-winter. The local climate is driven by the dominance of Equatorial Continental, Tropical Atlantic and occasionally Tropical Continental air masses during the summer. The Equatorial Continental air mass leads to high temperatures and humidity, with heavy rainfall events; the Tropical Atlantic air mass is also associated with the occurrence of strong convective rainfall, but of lower intensity than that associated with the Equatorial Continental mass. The summer weather only becomes drier, with little or no rainfall, when the Tropical Continental air mass prevails (FATMA 2002). In winter, the passage of the Atlantic Polar Front precedes the arrival of the Atlantic Polar Mass, which brings rainfall with thunderstorms followed by cold, dry air (FATMA 2002). At this point, tropical air masses are displaced to the centre and north of the country.

\section{Sampling design and data analysis}

Sampling and in situ experiments were performed on different temporal scales during the spring of 2012 and the summer of 2013, always at neap tide to 
minimize possible interferences. Sampling/experiment campaigns were performed in two months of each selected season (October and November; February and March), two weeks of each selected month and, finally, two days of each selected week. This class of experimental design is known as "fully nested". It is effective in assessing the variability of environmental data at several temporal scales (Morrisey et al. 1994, Bell et al. 1997) and can be properly analysed by hierarchical ANOVA (Underwood 1997). All four temporal scales (seasons, months, weeks and days), with two levels each, were considered as random factors, and the sampling was repeated at four adjacent sites (A-D) located approximately $300 \mathrm{~m}$ apart from each other, in the central part of the estuary, where depth ranged from 6 to $7 \mathrm{~m}$. Measurements obtained from each sampling site were true replicates, representing a source of variation to estimate changes in time.

Values $(n=72)$ of physicochemical parameters, nutrient concentrations and primary production and respiration rates were compared by ANOVA on different timescales (day, week, month and season), using the $\mathrm{R}$ software package version 2.13.1 (R Development Core Team 2012) and the GAD (Sandrini-Neto and Camargo 2010). The coefficient of variation was also estimated in order to determine the timescale in which the greatest variability occurred. Normality and homoscedasticity of data were tested by Shapiro-Wilk and Cochran analyses, respectively, and data were transformed by $\log (\mathrm{x})$ or square root when these assumptions were not met.

In order to verify the relationship between the environmental variables and phytoplankton taxa, a canonical analysis of principal coordinates (CAP) was conducted. Environmental variables were standardized and the values of phytoplankton abundance were transformed by $\log (x+1)$. The CAP analyses were performed from a matrix of Bray-Curtis similarity in the statistical package PRIMER and PERMANOVA 6.1.13+ version 1.0.3.

\section{Physicochemical and meteorological parameters}

Temperature, salinity and $\mathrm{pH}$ were recorded in the field using a standard $\mathrm{Hg}$ thermometer, a refractometer (ATAGO S1000) and a pH-meter (DENVER UP-25). The latter was calibrated before each sampling using standard buffers (Sinth). Water transparency was measured with a Secchi disc. In addition, 1-L subsurface water samples were collected with a van Dorn bottle, stored in vials and kept refrigerated in the dark. In the laboratory, approximately 5 hours after sample collection, samples $(250 \mathrm{ml})$ were filtered through Whatman $\mathrm{GF} / \mathrm{C}$ filters $(\varphi=47 \mathrm{~mm})$. The filtered liquid was used to determine dissolved inorganic nutrients (ammonium, nitrate, nitrite, phosphate and silicate) following the colorimetric method described by Grasshoff et al. (1983) in a spectrophotometer (SHIMADZU UV/V1601), and the suspended particulate matter (seston) was determined by the gravimetric technique (Strickland and Parsons 1972) from the material retained on the filters. To do this, the filters were maintained at $65^{\circ} \mathrm{C}$ for approximately $2 \mathrm{~h}$, cooled for $2 \mathrm{~h}$, and weighed on an analytical balance (Mettler H51AR). Additionally, 120-ml sample aliquots were immediately fixed after collection, preventing the formation of bubbles and the exposure to light and temperature variation until the determination of the dissolved oxygen (DO) concentration in the laboratory, approximately 5 hours after sample collection, following the titration method described in Grasshoff et al. (1983). During the field campaigns, hourly values of irradiance, rainfall, intensity and direction of the winds were obtained from an automatic meteorological station run by the National Institute of Meteorology (INMET) located in Itapoá, Santa Catarina State, approximately $10 \mathrm{~km}$ from the bay, and subsequently reported as daily averages. Wind data were not recorded in early October and irradiance measurements could not be computed on 26 October due to a technical failure in the anemometer and the pyranometer of the meteorological station, respectively. The pyranometer (Kipp \& Zonen ${ }^{\circledR}$, model CM6B) used has a spectral range of 310 to $2800 \mathrm{~nm}$ and is fully compliant with ISO 9060 specifications for a First Class pyranometer.

\section{Primary production and respiration rates in the water column $\left(\mathrm{O}_{2}\right.$ method $)$}

For the in situ incubation experiments with natural phytoplankton populations, at each of the four sampling sites seawater was collected from the entire water column using a transparent hose $(3 \mathrm{~cm}$ in diameter) containing a closing valve at one end and a weight at the other. The hose was gently deployed into the water, maintaining the valve kept on board open until the opposite tip of the stretched hose had touched the bottom. At that time, the valve was closed and the hose containing a full sample of the entire water column was brought to the boat deck, where the valve was opened and the sample was transferred to a van Dorn bottle. The sampled material was then distributed to BOD (biochemical oxygen demand) bottles with calibrated volumes for the incubation experiments. The samples were transferred to the bottles gently in order to avoid the formation of bubbles. The BOD bottles were then placed in acrylic tubes coated with layers of semitransparent plastic film of varying thickness, representing decreasing irradiance levels, and incubated on two independent floating frames for a period of $3 \mathrm{~h}$, always from 10:00 am to 1:00 pm. The two sets of tubes simulating decreasing irradiance levels yielded slightly different attenuation ratios: (i) 0, 5.7, 16.4, 20.2, 38, 42.9, 67.9 and $100 \%$ (dark tube); and (ii) $0,7.0,20.2,23.5$, 40.4, 46.5, 68.1 and $100 \%$. Zero and $100 \%$ attenuation were attained by tubes that were either uncovered or wrapped with several layers of black plastic film, respectively. The remaining attenuation levels were previously calculated in the laboratory by comparing the light intensity measured with a radiometer (Li-Cor LI1400) inside and outside each tube. At each sampling/ experimental site, one sample was immediately fixed to give the initial DO concentration at time zero. Thus, the rates of gross PP were simultaneously estimated at 
7 levels of luminosity, plus the rate of respiration of the community (dark flasks), and represented as the average value obtained from the duplicate series of BOD bottles. For the conversion of PP and respiration rates from DO to carbon units, a photosynthetic coefficient of 1.2 and a respiratory quotient of 1.0 were used, according to the literature (Asmus 1982, Biddanda et al. 1994, Almeida et al. 2005)

Based on the irradiance values (in $\mathrm{W} \mathrm{m}^{-2}$ ), the amount of photosynthetic active radiation (PAR, in $E \mathrm{~m}^{-2} \mathrm{~d}^{-1}$ ) was estimated using a conversion factor of 0.1944 , considering that the PAR spectral segment contribution to the global solar radiation ranges from 48.87 to $49.26 \%$ (mean $=49 \%$ ) in southern Brazil (Escobedo et al. 2011), and assuming a below-water-surface total quanta : total energy (Q:W) ratio of $2.5 \times 10^{18}$ quanta $\mathrm{s}^{-1}$ $\mathrm{W}^{-1}$ (Morel and Smith 1974).

From the converted PAR values, we calculated the depths corresponding to the simulated irradiance levels on each experiment day, using the model $\mathrm{Z}=\left(\left[\ln \mathrm{E}_{0}\right)-(\ln \right.$ $\left.\left.E_{z}\right)\right] / K$, where $Z$ is the depth corresponding to a given level of irradiance; $\mathrm{K}$ is the attenuation coefficient of light, calculated from the water transparency (Secchi) and a conversion factor of 1.44 (Holmes 1970); $\mathrm{E}_{0}$ is the amount of PAR at the surface; and $E_{z}$ is the PAR at a given simulated light level. Next, the rates of productivity were calculated for each depth and extrapolated for the entire photic zone through trapezoidal integration. Finally, PP measured during the incubation period was extrapolated to the entire light period of the day using the daily curve of PAR, as estimated from the data of the meteorological station. In addition, in order to investigate the variation in light availability during the study period, irradiance values were daily-averaged and expressed as standard PAR unit $\left(\mu \mathrm{E} \mathrm{m}^{-2} \mathrm{~s}^{-1}\right)$.

\section{Qualitative and quantitative analysis of phytoplankton}

Aliquots $(200 \mathrm{~mL})$ of the water sampled with a transparent hose along the entire water column, as described above, were placed in dark flasks containing Lugol's solution to a final concentration of $2 \%$ and stored for latter phytoplankton analysis. Phytoplankton enumeration and identification were performed on an inverted microscope (Zeiss Axiovert) using Utermöhl counting chambers after sedimentation of 10- or 25$\mathrm{mL}$ samples, depending on the cell density and seston concentration. The microphytoplankton $(>20 \mu \mathrm{m})$ was identified to the lowest possible taxon according to specific references such as Tomas et al. (1997), Steidinger and Jangen (1997) and Hoppenrath et al. (2009). A minimum of 500 cells of this size fraction was counted per sample in the entire counting chamber at $200 \mathrm{x}$ magnification, although the most abundant species were counted separately in transects. Less abundant species, such as the mixotrophic, toxic dinoflagellates belonging to the Dinophysis acuminata complex and their prey, the ciliate Mesodinium rubrum, were counted in parallel after settling an additional $50-\mathrm{mL}$ sample aliquot, as described above. Finally, the abundance of nanoplankton cells $(<20 \mu \mathrm{m})$ was determined by analysing multiple transects at a higher magnification $(400 \times)$ until $\sim 300$ cells were reached. In general, the counting accuracy remained at $\geq 90 \%$ confidence limit (Edler and Elbrachter 2010).

\section{RESULTS}

\section{Environmental and meteorological factors}

Over the spring of 2012 and the summer of 2013, October was the driest month, with a cumulative monthly rainfall of only $28.6 \mathrm{~mm}$ (Fig. 2A). Rainfall increased in November, December and January (177.2, 244.4 and $170.8 \mathrm{~mm}$, respectively), reaching a maximum in February and March (405.4 and $377.8 \mathrm{~mm}$ ). From late October to December, the predominant wind direction was $\mathrm{SW}$, with daily-averaged intensity ranging from 0.5 to $2 \mathrm{~m} \mathrm{~s}^{-1}$ (Fig. 2B). In February, the same pattern was observed, although there was a shift in wind direction to $\mathrm{E}$ in the second week. In March, unlike other months, winds were predominantly from the E quadrant, with a maximum daily-averaged intensity of $1.5 \mathrm{~m} \mathrm{~s}^{-1}$ (Fig. 2B). The average PAR for the entire sampling period was $740.7 \mu \mathrm{E} \mathrm{m}^{-2} \mathrm{~s}^{-1}$, with the highest values being recorded in November. During the sampling dates, daily-averaged values ranged from only $83.4 \mu \mathrm{E} \mathrm{m}^{-2} \mathrm{~s}^{-1}$ on 5 March, a fairly cloudy day, to $1281.7 \mu \mathrm{E} \mathrm{m}^{-2} \mathrm{~s}^{-1}$ on 20 November (Fig. 2C).

Generally, dissolved inorganic nutrients and other physicochemical parameters exhibited similar values
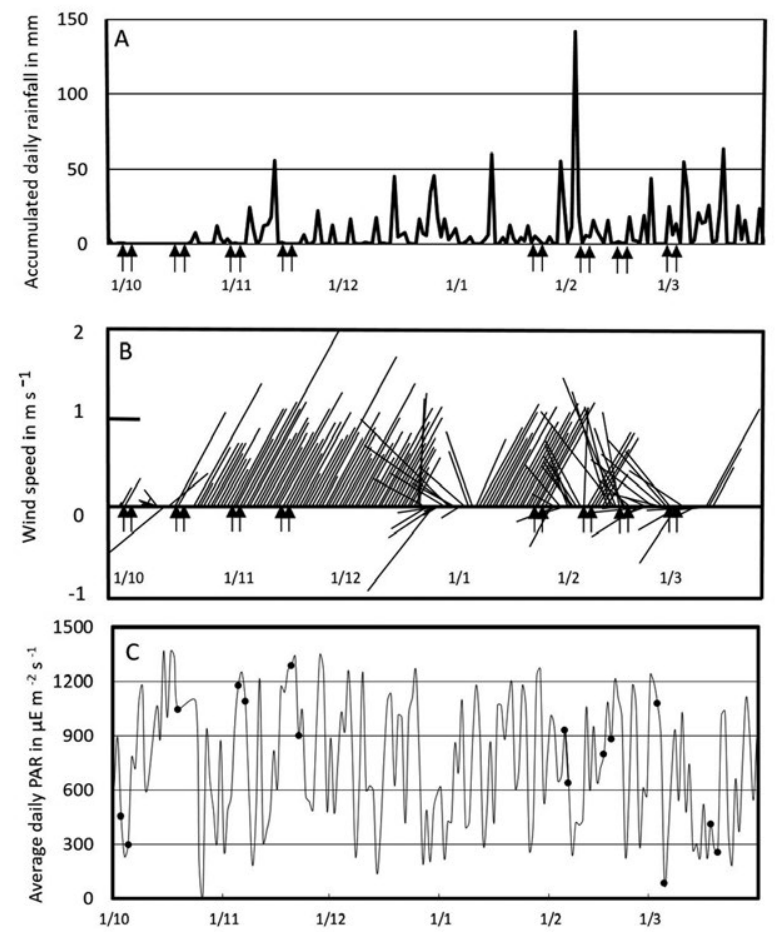

Fig. 2. - Temporal variation of (A) daily-accumulated rainfall, (B) daily-averaged wind direction and intensity, and $(\mathrm{C})$ daily-averaged mean photosynthetic active radiation (PAR) from October 2012 to March 2013 at Babitonga Bay, southern Brazil. Arrows placed on the X-axis in "A" and "B" indicate the dates of sampling/experiment campaigns; dark circles in " $C$ " represent the mean PAR on those dates. Wind data not recorded in early October; no PAR data available on 26 October. 

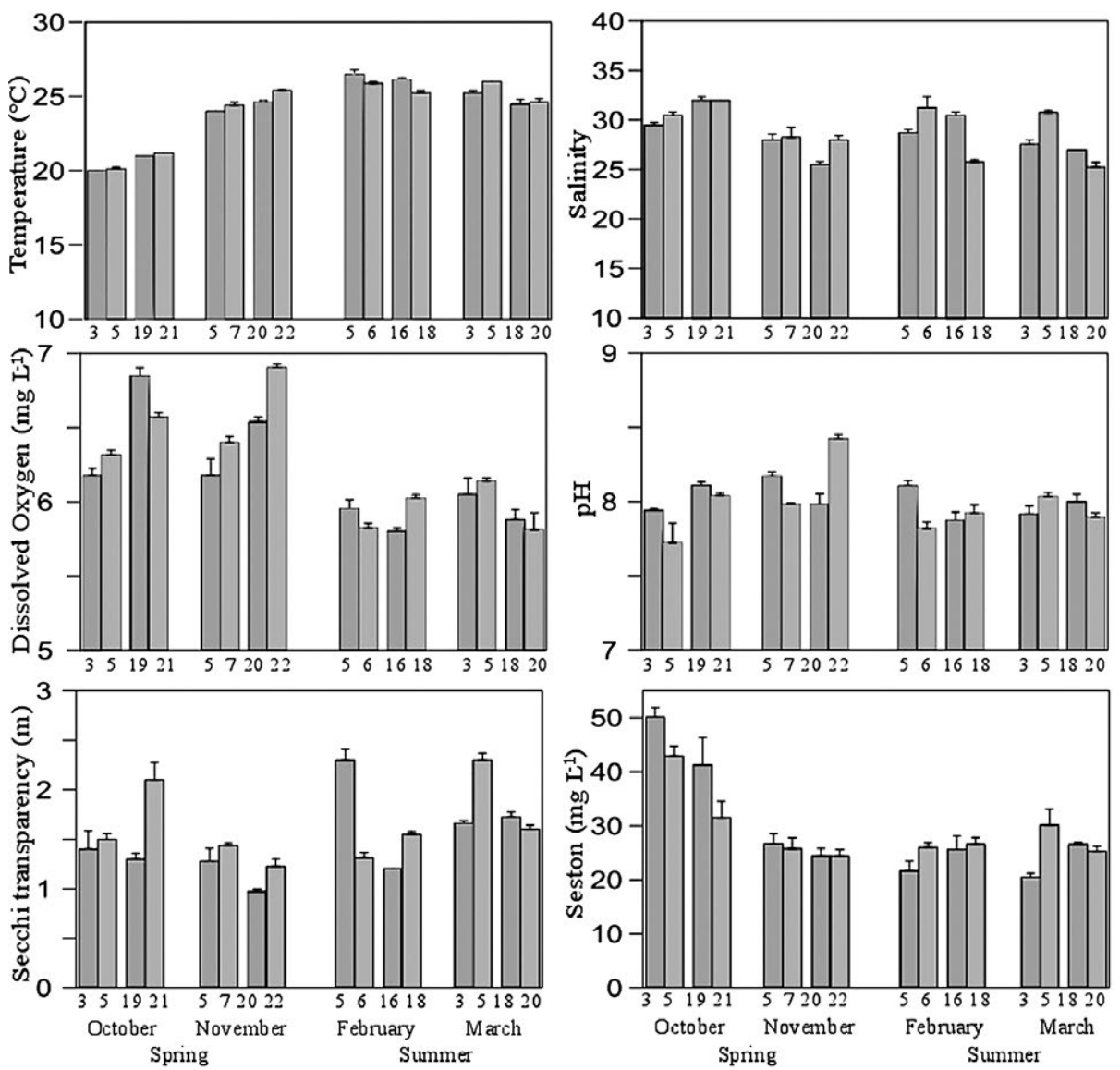

Fig. 3. - Variation (daily averages plus standard deviation) of water temperature, salinity, dissolved oxygen, pH, Secchi transparency and suspended particulate matter (seston) for each sampling day, from October 2012 to March 2013 at Babitonga Bay, southern Brazil.

among the sampling points for each collection day. Water temperature (daily-averaged values) increased from spring $\left(20^{\circ} \mathrm{C}\right)$ to summer $\left(27^{\circ} \mathrm{C}\right)$ (Fig. 3$)$, as expected. The analysis of variance components stressed that most of the variability was on the scale of months within seasons $(42.6 \%)$, followed by the seasons $(31.1 \%$, Table 1). The concentration of DO was higher in October and November (6.24 and $6.71 \mathrm{mg} \mathrm{L}^{-1}$, on average) than in the remaining months. In the summer, DO levels were similar between months and significantly lower than those measured in spring $(\mathrm{P}=0.004, \mathrm{CV}=45.1 \%$,
Table 1). On a few occasions, Secchi transparency was greater than $2 \mathrm{~m}$, as occurred on 5 February $(2.6 \mathrm{~m})$, although no significant differences between seasons, months within seasons or weeks within months were found. The variability was only significant $(\mathrm{P}<0.001)$ on the shortest timescale, between days within weeks $(\mathrm{CV}=44.2 \%$, Table 1$)$

Overall, there was a low variability in seston concentrations (monthly-averaged values of 25.2, 24.9 and $26.6 \mathrm{mg} \mathrm{L}^{-1}$ in November, February and March, respectively), with the exception of October, when the

Table 1. - Results of the analysis of variance comparing the values of water temperature, salinity, pH, seston, transparency (Secchi) and dissolved oxygen concentration measured on different time scales at four adjacent sampling sites (replicates) in Babitonga Bay, Santa Catarina State, southern Brazil. F, F-ratio; P, P-value; CV, coefficient of variation. P-values lower than 0.05 are highlighted in bold. ${ }^{1}$ Square roottransformed; ${ }^{2}$ Log-transformed

\begin{tabular}{|c|c|c|c|c|c|c|c|c|c|}
\hline & \multicolumn{3}{|c|}{ Temperature $^{1}$} & \multicolumn{3}{|c|}{ Salinity $^{2}$} & \multicolumn{3}{|c|}{$\mathrm{pH}$} \\
\hline & $\mathrm{F}$ & $\mathrm{P}$ & $\mathrm{CV}(\%)$ & $\mathrm{F}$ & $\mathrm{P}$ & $\mathrm{CV}(\%)$ & $\mathrm{F}$ & $\mathrm{P}$ & $\mathrm{CV}(\%)$ \\
\hline Season & 2.02 & 0.291 & 31.1 & 0.21 & 0.690 & 0.0 & 1.12 & 0.401 & 6.9 \\
\hline Month(Season) & 21.71 & 0.007 & 42.6 & 3.14 & 0.151 & 31.0 & 1.83 & 0.272 & 19.1 \\
\hline Week((Month)Season) & 4.89 & 0.027 & 11.8 & 1.46 & 0.294 & 16.8 & 0.81 & 0.550 & 0.0 \\
\hline Day(((Week)Month)Season) & 6.78 & $<0.001$ & 7.8 & 13.17 & $<0.001$ & 32.9 & 9.61 & $<0.001$ & 44.0 \\
\hline \multirow[t]{3}{*}{ Residual } & --- & --- & 6.5 & --- & --- & 19.2 & --- & --- & 30.0 \\
\hline & \multicolumn{3}{|c|}{ Seston } & \multicolumn{3}{|c|}{ Secchi } & \multicolumn{3}{|c|}{ Dissolved Oxygen } \\
\hline & $\mathrm{F}$ & $\mathrm{P}$ & $\mathrm{CV}(\%)$ & $\mathrm{F}$ & $\mathrm{P}$ & $\mathrm{CV}(\%)$ & $\mathrm{F}$ & $\mathrm{P}$ & $\mathrm{CV}(\%)$ \\
\hline Season & 1.04 & 0.414 & 0.0 & 2.14 & 0.281 & 19.0 & 234.79 & 0.004 & 45.1 \\
\hline Month(Season) & 10.53 & 0.025 & 43.0 & 1.67 & 0.296 & 16.0 & 0.04 & 0.956 & 0.0 \\
\hline Week((Month)Season) & 1.261 & 0.360 & 13.5 & 0.74 & 0.592 & 0.0 & 5.16 & 0.023 & 24.9 \\
\hline Day(((Week)Month)Season) & 3.63 & 0.002 & 19.3 & 19.01 & $<0.001$ & 44.2 & 5.96 & $<0.001$ & 15.8 \\
\hline Residual & --- & --- & 24.2 & --- & --- & 20.8 & --- & --- & 14.2 \\
\hline
\end{tabular}




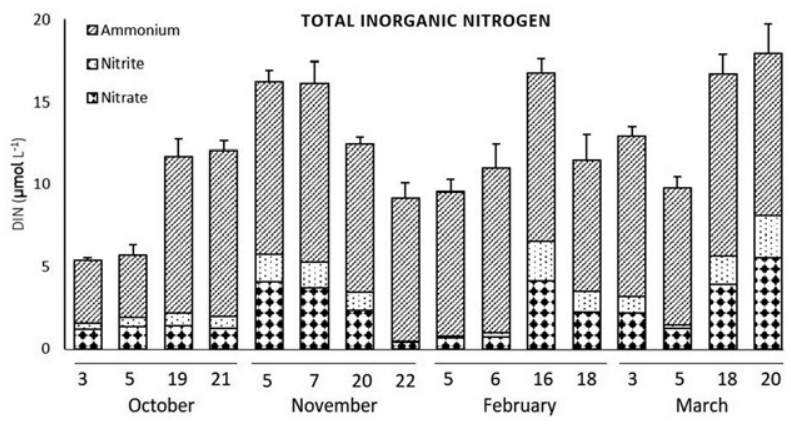

Fig. 4. - Concentrations (daily averages plus standard deviation) of nitrate, nitrite, ammonium and total dissolved inorganic nitrogen (DIN) for each sampling day, from October 2012 to March 2013 at Babitonga Bay, southern Brazil.

average concentration (41.4 $\mathrm{mg} \mathrm{L}^{-1}$, Fig. 3) was significantly higher $(\mathrm{P}=0.03$, Table 1$)$. Though most of the variability was due to the differences between months of a same season $(\mathrm{CV}=43 \%)$, a significant variation also occurred on the scale of days $(\mathrm{P}=0.002$, Table 1$)$. Salinity and $\mathrm{pH}$ exhibited a slight tendency to increase from the innermost to the outermost region of the bay, although the difference was not statistically significant. Salinity values varied widely between months within seasons ( $\mathrm{CV}=31 \%$, Table 1), although there was little variation between seasons. The highest daily-averaged salinity value (32) was recorded on 19 and 21 October
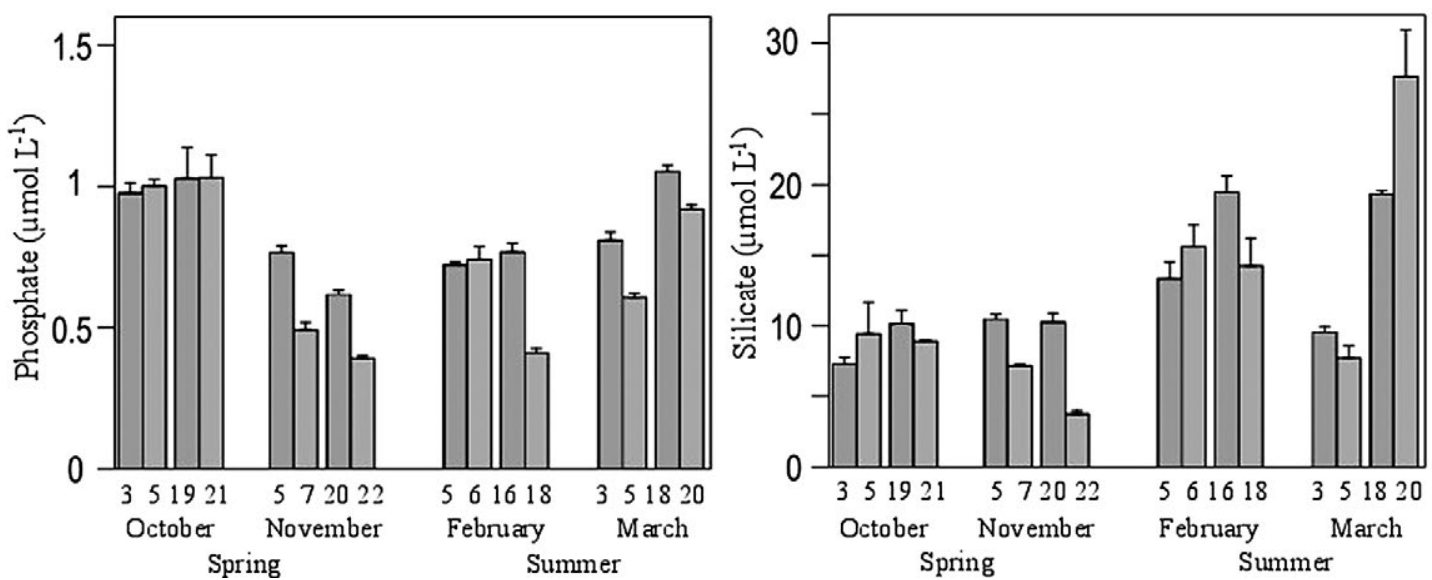

Fig. 5. - Concentrations (daily averages plus standard deviation) of phosphate and silicate for each sampling day, from October 2012 to March 2013 at Babitonga Bay, southern Brazil.

Table 2. - Results of the analysis of variance comparing the concentrations of nitrate, nitrite, ammonia, total inorganic nitrogen, phosphate and silicate measured on different time scales at four adjacent sampling sites (replicates) in Babitonga Bay, Santa Catarina State, southern Brazil. F, F-ratio; P, P-value; C.V., coefficient of variation. P-values lower than 0.05 are highlighted in bold.

\begin{tabular}{|c|c|c|c|c|c|c|c|c|c|}
\hline & \multicolumn{3}{|c|}{ Nitrate } & \multicolumn{3}{|c|}{ Nitrite } & \multicolumn{3}{|c|}{ Ammonia } \\
\hline & $\mathrm{F}$ & $\mathrm{P}$ & C.V. $(\%)$ & $\mathrm{F}$ & $\mathrm{P}$ & C.V. $(\%)$ & $\mathrm{F}$ & $\mathrm{P}$ & C.V.(\%) \\
\hline Season & 0.32 & 0.628 & 0.0 & 0.21 & 0.690 & 7.0 & 0.64 & 0.507 & 0.0 \\
\hline Month(Season) & 0.46 & 0.659 & 0.0 & 0.18 & 0.840 & 0.0 & 0.85 & 0.493 & 0.0 \\
\hline Week((Month)Season) & 5.04 & 0.025 & 56.1 & 3.83 & 0.050 & 51.0 & 15.89 & $<0.001$ & 59.1 \\
\hline Day(((Week)Month)Season) & 26.42 & $<0.001$ & 29.6 & 71.71 & $<0.001$ & 30.5 & 3.74 & $<0.001$ & 18.5 \\
\hline \multirow[t]{3}{*}{ Residual } & -- & --- & 14.3 & --- & --- & 11.4 & -- & --- & 22.4 \\
\hline & \multicolumn{3}{|c|}{ DIN } & \multicolumn{3}{|c|}{ Phosphate } & \multicolumn{3}{|c|}{ Silicate } \\
\hline & $\mathrm{F}$ & $\mathrm{P}$ & C.V.(\%) & $\mathrm{F}$ & $\mathrm{P}$ & C.V. $(\%)$ & $\mathrm{F}$ & $\mathrm{P}$ & C.V.(\%) \\
\hline Season & 0.68 & 0.495 & 0.0 & 0.00 & 0.963 & 0.0 & 92.91 & 0.010 & 33.4 \\
\hline Month(Season) & 0.91 & 0.472 & 0.0 & 7.37 & 0.045 & 44.2 & 0.05 & 0.953 & 0.0 \\
\hline Week((Month)Season) & 9.23 & 0.004 & 57.2 & 1.04 & 0.442 & 13.3 & 4.55 & 0.032 & 31.1 \\
\hline Day(((Week)Month)Season) & 12.84 & $<0.001$ & 27.1 & 26.57 & $<0.001$ & 26.2 & 7.83 & $<0.001$ & 18.7 \\
\hline Residual & --- & --- & 15.7 & --- & --- & 16.3 & --- & --- & 16.7 \\
\hline
\end{tabular}


Table 3. - Results of the analysis of variance comparing the rates of respiration and primary production, and the total abundance of nano- and microphytoplankton measured on different time scales at four adjacent sampling sites (replicates) in Babitonga Bay, Santa Catarina State, southern Brazil. F, F-ratio; P, P-value; C.V., coefficient of variation. P-values lower than 0.05 are highlighted in bold.

\begin{tabular}{|c|c|c|c|c|c|c|c|c|c|c|c|c|}
\hline & \multicolumn{3}{|c|}{ Respiration } & \multicolumn{3}{|c|}{ Primary Production } & \multicolumn{3}{|c|}{ Nanoplankton } & \multicolumn{3}{|c|}{ Microphytoplankton } \\
\hline & $\mathrm{F}$ & $\mathrm{P}$ & C.V.(\%) & $\mathrm{F}$ & $\mathrm{P}$ & C.V. $(\%)$ & $\mathrm{F}$ & $\mathrm{P}$ & C.V.(\%) & $\mathrm{F}$ & $\mathrm{P}$ & C.V.(\%) \\
\hline Season & 257.00 & 0.003 & 21.4 & 0.00 & 0.995 & 0.0 & 1.05 & 0.412 & 0.4 & 0.13 & 0.753 & 0.0 \\
\hline Month(Season) & 0.05 & 0.952 & 0.0 & 7.59 & 0.043 & 36.4 & 1.59 & 0.314 & 1.5 & 2.60 & 0.188 & 12.3 \\
\hline Week((Month)Season) & 0.40 & 0.804 & 0.0 & 1.19 & 0.385 & 0.0 & 0.60 & 0.671 & 0.0 & 5.68 & 0.018 & 49.0 \\
\hline Day(((Week)Month)Season) & 2.28 & 0.036 & 9.8 & 3.44 & 0.003 & 30.5 & 5.63 & $<0.001$ & 48.3 & 80.95 & $<0.001$ & 37.8 \\
\hline Residual & --- & --- & 68.8 & -- & --- & 33.0 & --- & -- & 49.8 & -- & --- & 0.8 \\
\hline
\end{tabular}
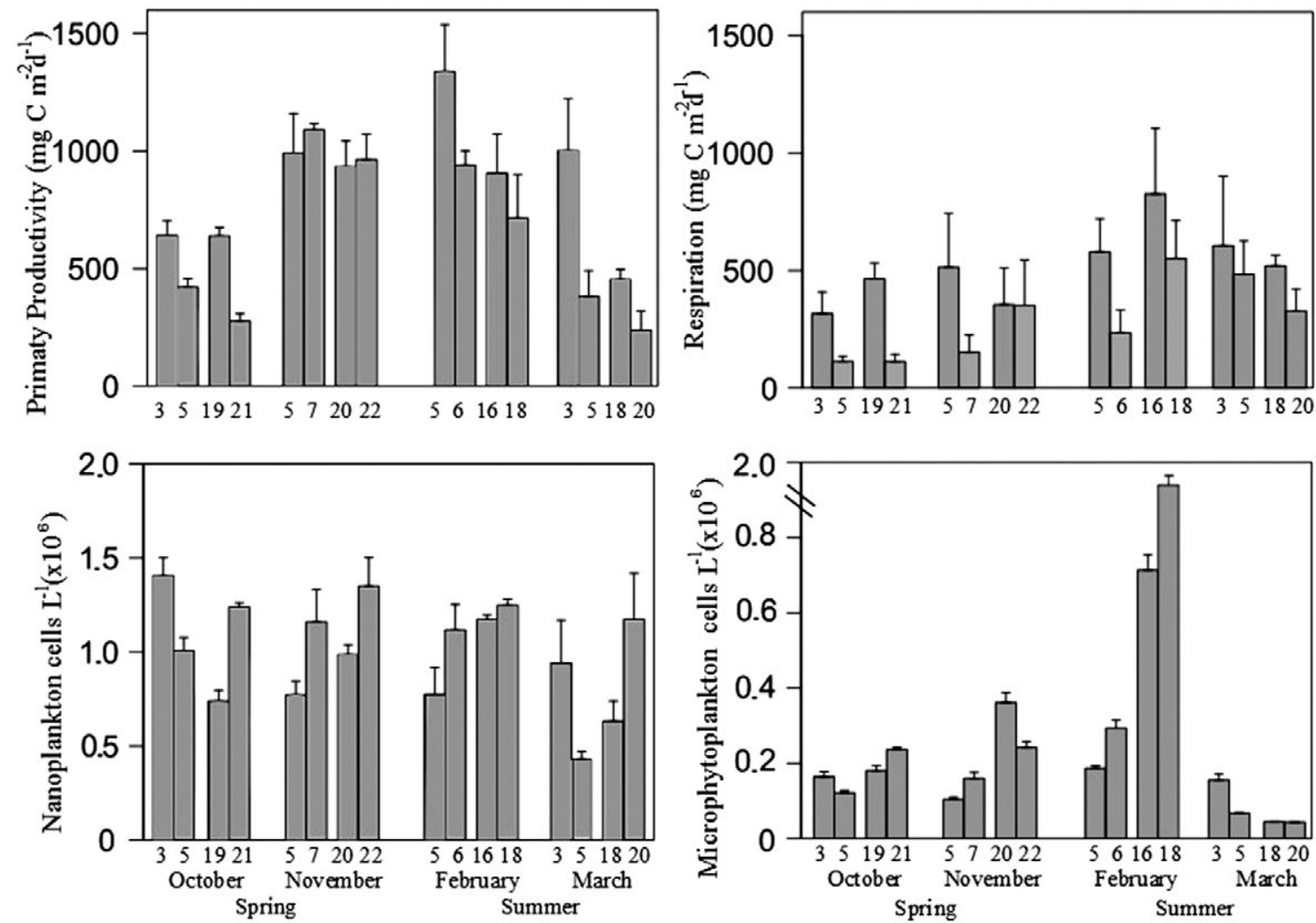

Fig. 6. - Monthly-averaged values (plus standard deviation) of respiration, primary productivity and total abundance of nanophytoplankton and microphytoplankton from October 2012 to March 2013 at Babitonga Bay, southern Brazil.

Phosphate varied significantly on the scale of days $(\mathrm{P}$ $<0.001$ ), but mostly between months within seasons (44.1\% of the variability; Table 2). The highest concentration of phosphate in October, with average of 1 umol L ${ }^{-1}$ (Fig. 5) resulted in the lowest N:P ratio calculated over the entire study period (average of 8.7). In all other months, $\mathrm{N}: \mathrm{P}$ ratios were generally $>16$, with the maximum value being recorded on 7 November (33.2). Silicate concentrations were significantly lower $(\mathrm{P}=0.005, \mathrm{CV}=33.4 \%)$ in the spring (8.94 and 7.91 $\left.\mu \mathrm{mol} \mathrm{L} \mathrm{L}^{-1}\right)$ than in the summer $(15.65$ and $16.06 \mu \mathrm{mol}$ $\left.\mathrm{L}^{-1}\right)$. Large variations were also observed on the scale of weeks within months $(\mathrm{CV}=31.1 \%)$.

\section{Primary production rates, composition and abundance of phytoplankton}

The daily-averaged values of primary production (PP) rate, integrated to the entire water column, varied mostly on the scales of months within seasons $(\mathrm{P}=0.043)$ and days within weeks $(\mathrm{P}=0.003$, Table 3$)$.
These significant differences between the monthly averages were observed both in spring and in summer. The highest PP rates occurred in November and February, when the monthly-averaged values were 994.9 and $974.7 \mathrm{mg} \mathrm{C} \mathrm{m}^{-2} \mathrm{~d}^{-1}$, respectively (Fig. 6). The greatest variation in PP rates within a single month was recorded in March, ranging from $237.9 \mathrm{mg} \mathrm{C} \mathrm{m}^{-2} \mathrm{~d}^{-1}$ on 3 March to $1001.3 \mathrm{mg} \mathrm{C} \mathrm{m} \mathrm{m}^{-2} \mathrm{~d}^{-1}$ on 20 March (Fig. $6)$. Respiration rates in the water column were higher in summer than in spring $(\mathrm{P}=0.003$, Table 3$)$, reaching the highest monthly-averaged value of $547.8 \mathrm{mg}$ $\mathrm{C} \mathrm{m}^{-2} \mathrm{~d}^{-1}$ in February, and the highest daily-averaged value of $825.6 \mathrm{mg} \mathrm{C} \mathrm{m}^{-2} \mathrm{~d}^{-1}$ on 16 February (Fig. 6). In March, respiration rates decreased slightly, although they remained higher than in October $\left(251.5 \mathrm{mg} \mathrm{C} \mathrm{m}^{-2}\right.$ $\left.\mathrm{d}^{-1}\right)$ and November (343.3 $\left.\mathrm{mg} \mathrm{C} \mathrm{m}^{-2} \mathrm{~d}^{-1}\right)$.

Large variability in the total abundance of phytoplankton cells was only observed on smaller timescales, between days for nanophytoplankton and between days and weeks for microphytoplankton. Monthly-averaged values of nanophytoplankton abundance were similarly 


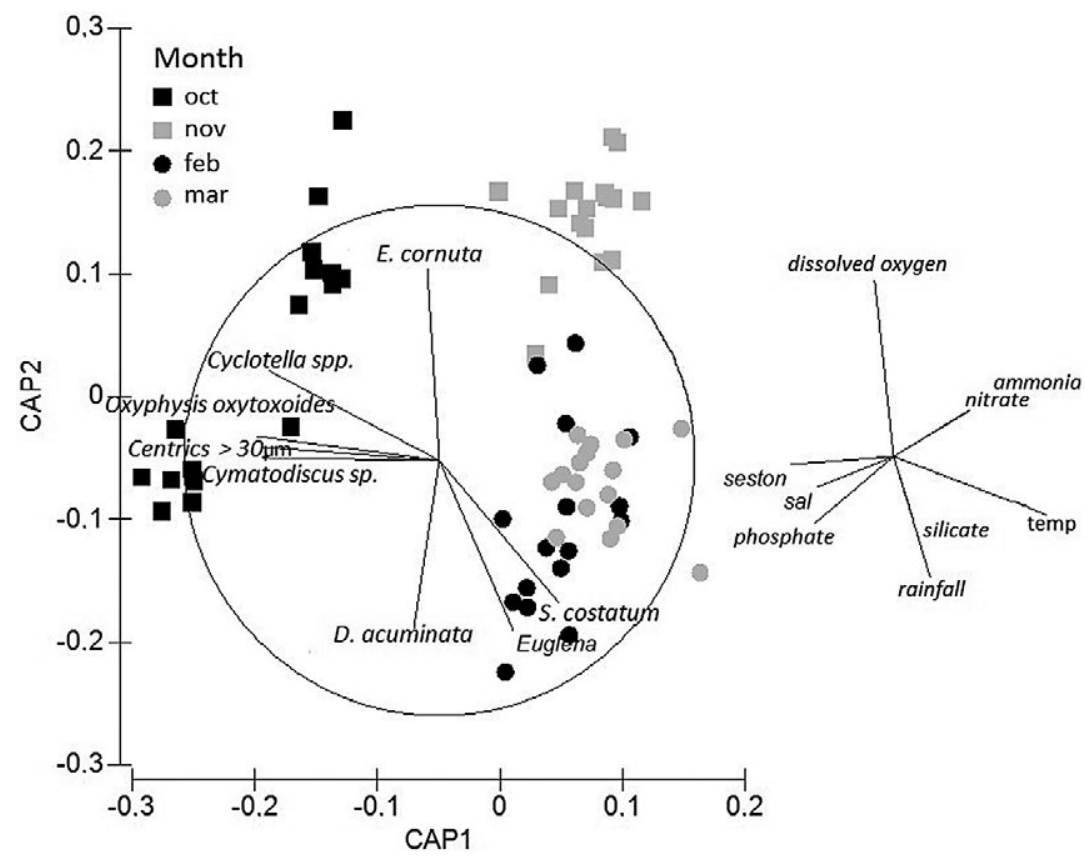

Fig. 7. - Results of the canonical analysis of principal coordinates relating the variation patterns of the seasonal phytoplankton associations to the physicochemical parameters investigated from October 2012 to March 2013 at Babitonga Bay, southern Brazil.
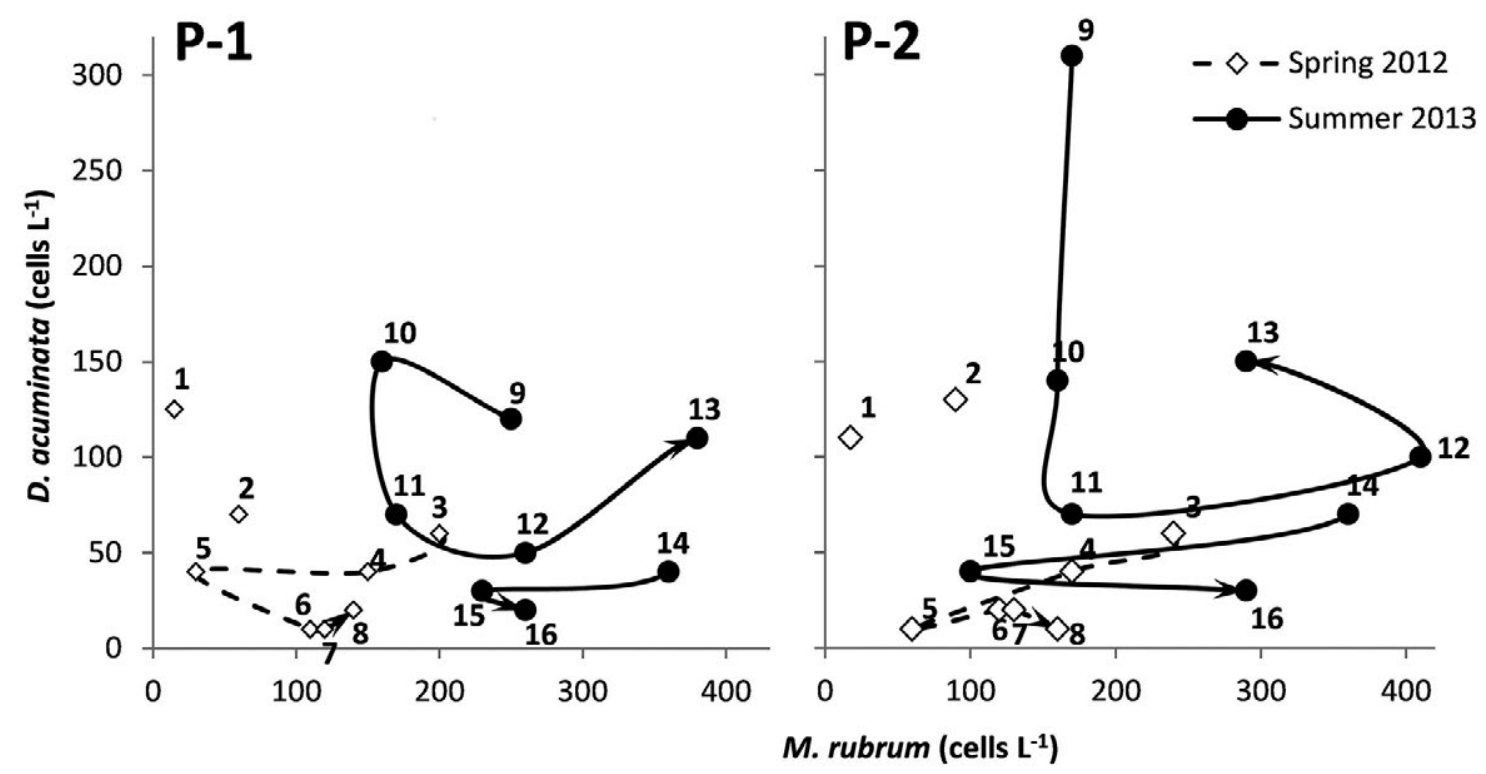

Fig. 8. - Temporal variation in the cell abundance of the ciliate Mesodinium rubrum (prey) and the dinoflagellate Dinophysis acuminata complex (predator) over the 16 sampling dates, from October to December 2012 (spring) and from February to March 2013 (summer) at two sampling points (P-1, P-2) at Babitonga Bay, southern Brazil. Arrows highlight temporal anti-clockwise orbits in the prey-predator relationship.

high $\left(\sim 1.1 \times 10^{6}\right.$ cells $\left.\mathrm{L}^{-1}\right)$ throughout the study, with the exception of March $\left(0.8 \times 10^{6}\right.$ cells $\left.\mathrm{L}^{-1}\right)$. Daily-averaged values ranged from 0.4 to $1.4 \times 10^{6}$ cells $\mathrm{L}^{-1}$. Microphytoplankton abundance was generally lower $\left(<0.3 \times 10^{6}\right.$ cells $\mathrm{L}^{-1}$ ) than nanophytoplankton abundance, with the exception of the second weeks of November and February, when expressive differences between the daily averages were observed and high cell abundances were recorded $\left(0.7-1.8\right.$ and $0.7-1.7 \times 10^{6}$ cells $\mathrm{L}^{-1}$, respectively, Fig. 6).

In total, 53 different microphytoplankton taxa were identified in this study, including 41 diatoms (Bacillariophyceae), 10 dinoflagellates (Dinophyceae), one euglenophyte and one silicoflagellate. Some taxa were frequent and relatively abundant throughout the study period, such as the benthic diatoms Cylindrotheca closterium, Paralia sulcata, Psamodictyon panduriformis, Diploneis spp., Navicula spp., the planktonic Thalassionema frauendeldii, Thalassionema nitszchioides, Thalassiosira spp., and the dinoflagellates of the genera Gymnodinium, Gyrodinium, Prorocentrum and Protoperidinium.

Other taxa were more frequent and abundant during specific periods. For instance, T. frauenfeldii, the benthic diatoms Cyclotella spp. and Cymatodiscus planetophorus, and other larger $(>30 \mu \mathrm{m})$ centric 
diatoms, as well as the dinoflagellate Oxyphysis oxytoxoides, were abundant in spring but rare or absent in summer. These taxa formed a well-defined spring phytoplankton assemblage associated with higher salinity, phosphate and seston concentrations and lower DIN values (Fig. 7). In addition, another diatom, Eucampia cornuta, was rarely detected in summer but was recorded at high cell densities during an intermittent bloom episode $\left(0.2 \times 10^{6}\right.$ cells $\left.\mathrm{L}^{-1}\right)$ in the second week of November (spring), when DO concentrations were higher (Fig. 7). Conversely, Skeletonema costatum was rarely observed in spring, but attained very high cell densities in summer (up to $1.3 \times 10^{6}$ cells $\mathrm{L}^{-1}$ in the first week of February). In addition to $S$. costatum, Corethron criophilum, Leptocylindrus minimus and other small-sized centric diatoms, as well as an unidentified euglenophyte species, formed a characteristic summer phytoplankton assemblage associated with lower DO values and higher temperature, rainfall and silicate concentration (Fig. 7).

Finally, toxic dinoflagellates belonging to the Dinophysis acuminata complex were frequently recorded at low cell densities (10 to 310 cells $\mathrm{L}^{-1}$ ) and their abundance was not clearly related to any of the physicochemical parameters investigated (Fig. 7). Instead, the abundance of this mixotrophic organism was somehow dependent on the availability of its prey, the ciliate Mesodinium rubrum, as suggested by the temporal anti-clockwise orbits partially formed when the cell abundances of both taxa were compared (Ishikawa et al. 2014) in Figure 8. At least in summer months, an increase in $D$. acuminata abundance led to a decrease in $M$. rubrum cell density and vice-versa (Fig. 8). $M$. rubrum was present in all samples over the period of study, at cell densities ranging from 10 to 440 cells L ${ }^{-1}$.

\section{DISCUSSION}

We have demonstrated herein that the main physicochemical characteristics of the water column vary on different timescales in a subtropical estuary, Babitonga Bay, which explains the high variability in phytoplankton production, abundance and composition commonly reported in this type of environment.

The variability of water column characteristics in estuaries is mainly determined by local hydrology, which in turn is a result of the processes and interactions occurring at the interface between oceanic and continental environments. In this dynamic zone, tides, atmospheric fronts, wind action, and fluctuations in rainfall and river flow promote a constant exchange between contrasting water bodies (Cloern and Jassby 2010, Abreu et al. 2010, Maier et al. 2012). In the present study, large differences were observed on short timescales (days to weeks) for parameters such as salinity, $\mathrm{pH}$, water transparency and DIN concentration and on a longer scale (months to seasons) for temperature, DO, seston, silicate and phosphate concentrations, reflecting complex shifts in the dominant hydrodynamic conditions that ultimately affect phytoplankton abundance and composition. Salinity, $\mathrm{pH}$ and concentrations of dissolved nutrients were comparable to the range of values reported by previous studies in Babitonga Bay (Cremer et al. 2006, Camacho and Souza-Conception 2007, Villar et al. 2011), but this is the first attempt to determine the temporal scale on which they vary, allowing a more proper indication of cause-effect relationships.

The marked differences in silicate and phosphate concentrations on a large temporal scale, for instance, can be explained by the great variation in rainfall and wind-driven turbulence observed over the course of this study. The highest concentrations of silicate recorded in February and March were the result of increased continental drainage due to the heavier rainfall observed in summer than in spring. In contrast, re-suspension of recycled forms from the bottom by wind-driven water turbulence may be a more important source for less abundant nutrients such as phosphate. This finding may explain the higher concentrations of phosphate observed in October, when higher seston loads and relatively low transparency values (as assessed by Secchi disc) suggest a period of more intense water turbulence, although there are no wind data available for that specific period to confirm this.

Phytoplankton dynamics may also influence the biogeochemical cycles in estuaries, in addition to regional weather events and tide fluctuations. According to Cloern and Jassby (2010), nutrient concentrations and other environmental variables such as $\mathrm{pH}$ and DO may experience greater fluctuations when phytoplankton blooms are frequent. In the present study, the diatom species Skeletonema costatum, Guinardia sp., Eucampia cornuta and Corethron criophilum attained high cell abundances over a relatively short period of time, suggesting that phytoplankton blooms may play a key role in biogeochemical cycles in Babitonga Bay. Accordingly, the concentrations of ammonia and nitrate, nitrogen forms preferentially used by primary producers, varied on a small temporal scale (days to weeks) and were negatively related to phytoplankton abundance in the present study. In addition, lower DO concentrations measured in February and March coincided with greater respiration rates relative to spring months, probably linked to the decay of $S$. costatum and Guinardia sp. blooms and the associated bacterial decomposition of excessive organic matter generated at the end of those events. Higher influx of organic matter to the estuarine system, as well as the higher water temperature-and consequently the lower gassolubilization capacity - typical of the austral summer in southern Brazil, may also contribute to the lower DO concentrations during that period. A similar decrease in DO concentration during summer has been previously reported in Chesapeake Bay, USA (Kemp et al. 1992) and Daya Bay, China (Song et al. 2004).

The rates of PP varied enormously in this study, ranging from 10.5 to $1793 \mathrm{mg} \mathrm{C} \mathrm{m}^{-2} \mathrm{~d}^{-1}$, which is within the range reported for other subtropical and temperate estuaries (Table 4), where PP is highly variable on a temporal and/or spatial scale. In contrast, Song et al. (2004) reported higher PP rates (239.7 to $2721.9 \mathrm{mg} \mathrm{C}$ $\mathrm{m}^{-2} \mathrm{~d}^{-1}$ ) during spring and summer in Daya Bay, China, where the size structure and the biomass of the phytoplankton assemblage are reasonably constant overtime. 
Table 4. - Summary of the primary production rates measured in some estuarine systems.

\begin{tabular}{lcr}
\hline Place & PP $\left(\mathrm{mg} \mathrm{C} \mathrm{m}^{-2} \mathrm{~d}^{-1}\right)$ & Reference \\
\hline Babitonga Bay (Brazil) & $10.5-1793$ & Present study \\
Arcachon Bay (France) & $<50-496.6$ & Glé et al. 2008 \\
San Francisco (USA) & $\sim 20-1000$ & Kimmerer et al. 2012 \\
Apalachicola Bay (USA) & $90-1800$ & Mortazavi et al. 2000 \\
Douro (Portugal) & $4.7-1878.5$ & Azevedo et al. 2006 \\
Urdaibai (Spain) & $0.002-2828$ & Iriarte et al. 1996 \\
Chesapeake Bay (USA) & $500-3500$ & Malone et al. 1996 \\
\hline
\end{tabular}

In the present study, PP varied on different timescales (days and months), with higher values observed in November, when more intense PAR and clear-sky conditions coincided with the period of sampling/experiments. In October, February and March, conversely, PAR values were mostly low and the weather predominantly cloudy with some sunny spells during the field campaigns, with the exception of 3 March, when sunny conditions and high PP were simultaneously observed again. Likewise, a change in meteorological conditions with the reduction of light availability two days later, on 5 March (Fig. 2C), was followed by a dramatic decrease in PP (Fig. 6). In addition to local meteorological conditions affecting light availability to the water surface, high seston loads can greatly reduce light penetration over the water column in estuaries, potentially limiting phytoplankton production by narrowing the photic zone (Cloern 1987). In fact, periods of higher seston concentration coincided with low PP rates in the present study, and this finding was particularly noticeable in early October (Figs 3 and 6). Therefore, light availability, which is mainly controlled by local weather and secondarily by suspended matter loads, can be regarded as the main factor regulating phytoplankton production in Babitonga Bay, as has also been observed in the Bay of San Francisco, USA (Kimmerer et al. 2012) and other estuarine areas (Domingues et al. 2011, Cloern et al. 2014).

The expected relationship between PAR and PP, however, can be affected by shifts in the phytoplankton assemblage, which may contribute to short-timescale variability in PP. In the present study, the highest PP rates coincided with the period (early November) when the phytoplankton assemblage was dominated by multiple species of relatively larger cell size, such as Cyclotella spp., Cymatodiscus spp. and other centric diatoms $>30 \mu \mathrm{m}$. Similarly, high photosynthetic rates were associated with higher species diversity and larger mean cell volume over a tidal cycle in Baie des Vies, northwestern France (Jouenne et al. 2005). In Babitonga Bay, relatively high PP rates were also reported during periods when small-celled diatoms were dominant, such as E. cornuta in the second half of November and S. costatum in February, but only when they attained bloom cell densities. In this case, high PP and respiration rates could be recorded in spite of lower PAR values, as recorded during the development of a summer S. costatum bloom in the present study, and previously reported by Almeida et al. (2005) during and after bloom episodes in Ria de Aveiro, Portugal. Thus, high PP rates in Babitonga Bay can be produced either by moderate abundances of relatively large-celled pro- ducers (spring) or during blooms dominated by one or a few small-celled species (summer), especially when solar radiation is high and seston load low.

Blooms of S. costatum are common during summer months in southern Brazilian estuaries, including the nearby estuarine complex of Paranaguá Bay (Brandini 1985, Mafra Jr. et al. 2006) and the inner sector of Babitonga Bay (Parizzi et al. 2013). S. costatum blooms are triggered when the irradiance becomes high enough to reach the bottom (Shikata et al. 2008), promoting the germination of resting cells present on the sediment, followed by rapid growth of the vegetative cells under high temperature. Such conditions of high luminosity and temperature were present in February when the bloom of $S$. costatum was recorded in the present study. The detection of this bloom in the intermediate sector of Babitonga Bay, contrary to previous reports in which the bloom was restricted to the inner sector of the estuary (Parizzi et al. 2013), can probably be explained by the fact that all sampling campaigns were performed during neap tide in the present study, but spring tide in the latter. The lower tidal range may have favoured the transport of cells to the outer region of the estuary (Maier et al. 2012) in our study.

While the variability in the abundance of nano- and microphytoplankton was noticeable only on the shorter timescales, their specific abundance and species composition were quite dynamic and differed on various timescales. Similarly, studies carried out by Fujita and Odebrecht (2007) and Abreu et al. (2010) in the estuarine system of Patos Lagoon, on the southernmost portion of the Brazilian coast, also reported marked variability on short timescales for the phytoplankton taxonomic composition, chlorophyll $a$ concentration and various environmental parameters. According to those authors, the dominant hydrodynamic conditions determined by the wind direction were related to variability on short timescales (hours to weeks), while the rainfall regime was more important on a longer scale (months to years). In addition to the wind action and precipitation cycles, which are more important in estuaries with little water exchange and a restricted connection with the adjacent ocean, such as Patos Lagoon (Fujita and Odebrecht 2007, Abreu et al. 2010), tidal fluctuations may be another important source of variability on a short timescale, especially in more open and dynamic estuaries like Babitonga Bay. As a result, physicochemical parameters vary on different timescales and ultimately affect phytoplankton abundance and succession. In fact, during the present study, spring mixed assemblages dominated by large diatoms were associated with higher salinity, phosphate and seston concentrations and lower DIN values, while euglenophytes and small-sized bloom-forming diatoms formed a characteristic summer assemblage associated with higher temperature, rainfall and silicate concentration.

Some other phytoplankton taxa, such as the toxic dinoflagellates belonging to the Dinophysis acuminata complex, were frequent throughout the study, as recorded in the nearby Guaratuba Bay (Tibiriçá et al. 2015), but their abundances were not clearly related to any of the physicochemical parameters evaluated 
in the present study. Instead, the abundance of this mixotrophic alga was partially related to that of its prey, the kleptoplastidic ciliate Mesodinium rubrum, as suggested by the temporal anti-clockwise orbits formed when the cell abundances of both taxa were plotted against each other. This relationship, originally used to describe the prey-predator interactions between heterotrophic nanoflagellates and bacteria (Tanaka et al. 1997), was recently described for D. acuminata and M. rubrum in Japan (Ishikawa et al. 2014). Although the abundance of $D$. acuminata complex cells was relatively low in the present study (maximum 310 cells $\mathrm{L}^{-1}$ ), they may produce large levels of toxin, so cell densities as low as 100-200 cells $\mathrm{L}^{-1}$ may be sufficient to cause hazardous outbreaks in human consumers of contaminated bivalves (Yasumoto et al. 1985). In addition, diarrheic shellfish toxins may also cause immunotoxicity, genotoxicity and cytotoxicity to many cell types (reviewed in Valdiglesias et al. 2013), and even tumour formation upon chronic exposure (Fujiki and Suganuma 2009).

\section{CONCLUSIONS}

The present results reveal a marked variability in PP, composition and abundance of phytoplankton, and in environmental factors on different timescales in Babitonga Bay. Marked short-scale variability in the physicochemical parameters was accompanied by quick changes in PP and phytoplankton abundance and composition. In addition to the presumed influence of winds and precipitation cycles, tidal periodicity was a chief mechanism regulating this variability on the scales of days and weeks. Changes in PP rates resulted mainly from shifts in light availability due to monthly PAR oscillations and water turbidity, but also from variations in the specific composition and abundance of phytoplankton. High PP rates were associated with either moderate abundances of larger centric diatoms or bloom concentrations of small cells. Although variations in the total abundance of nano- and microphytoplankton occurred mostly on the scale of days and weeks, their taxonomic composition and specific abundances were fairly dynamic, varying markedly on various timescales. Future studies in estuarine ecosystems should consider such short-timescale variability in order to obtain truly representative and ecologically relevant measurements.

\section{REFERENCES}

Abreu P.A., Bergesch A., Proença L.A., et al. 2010. Short- and longterm chlorophyll- $a$ variability in the shallow microtidal Patos Lagoon estuary, southern Brazil. Estuar. Coast. 33: 554-569. http://dx.doi.org/10.1007/s12237-009-9181-9

Asmus R. 1982. Field measurements on seasonal variation of the activity of primary producers on a sandy tidal flat in the Northern Wadden Sea. J. Sea Res. 16: 389-402. http://dx.doi.org/10.1016/0077-7579(82)90045-X

Almeida M.A., Cunha M.A., Alcântara F. 2005. Relationship of bacterioplankton production with primary production and respiration in a shallow estuarine system (Ria de Aveiro, NW Portugal). Microb. Res. 160: 315-328. http://dx.doi.org/10.1016/j.micres.2005.02.005

Azevedo I.C., Duarte P.M., Bordalo A.A. 2006. Pelagic metabolism of the Douro estuary (Portugal): Factors controlling primary production. Est. Coast. Shelf Sci. 69: 133-146. http://dx.doi.org/10.1016/j.ecss.2006.04.002

Bell R.G., Hume T.M., Dolphin T.J., et al. 1997. Characterization of physical environmental factors on an intertidal sandflat, Manukau Harbour, New Zealand. J. Exp. Mar. Biol. Ecol. 216: 11-31. http://dx.doi.org/10.1016/S0022-0981(97)00088-9

Biddanda B., Ogdahl S., Benner R. 1994. Plankton respiration and carbon flux through bacterioplankton on the Louisiana shelf. Limnol. Oceanogr. 39: 1259-1275. http://dx.doi.org/10.4319/1o.1994.39.6.1259

Brandini F.P. 1985. Seasonal succession of the phytoplankton in the bay of Paranaguá (Paraná State - Brazil). Braz. J. Biol. 45: 687-694.

Camacho F.P. Souza-Conceição J.M. 2007. Distribuição espaçotemporal da clorofila-a e variáveis ambientais em praias estuarinas da ilha de São Francisco do Sul, Santa Catarina (Baía da Babitonga, Sul do Brasil). Bol. Tec. Cient. CEPENE. 15: 9-19 (in Portuguese).

Chen C.T.A., Borges A.V. 2009. Reconciling opposing views on carbon cycling in the coastal ocean: Continental shelves as sinks and near-shore ecosystems as sources of atmospheric $\mathrm{CO}_{2}$. Deep-Sea Res. part II. 56: 578-590. http://dx.doi.org/10.1016/j.dsr2.2009.01.001

Cloern J.E. 1987. Turbidity as a control on phytoplankton biomass and productivity in estuaries. Cont. Shelf Res. 7: 1367-1381. http://dx.doi.org/10.1016/0278-4343(87)90042-2

Cloern J.E., Jassby A.D. 2010. Patterns and scales of phytoplankton variability in estuarine-coastal ecosystems. Estuar. Coast. 33: 230-241.

http://dx.doi.org/10.1007/s12237-009-9195-3

Cloern J.E., Foster S.Q., Kleckner A.E. 2014. Phytoplankton primary production in the world's estuarine-coastal ecosystems. Biogeosciences 1: 2477-2501. http://dx.doi.org/10.5194/bg-11-2477-2014

Cremer M.J., Morales R.D.P., Oliveira M.N. 2006. Diagnóstico ambiental da Baía da Babitonga. UNIVILLE, Joinville, Brazil, 256 pp (in Portuguese).

DENIT/IME. 2004. Estudos Ambientais da Baía da Babitonga - Canal do Linguado. Relatório Final dos Estudos da Baía da Babitonga/Canal do Linguado. Convênio DENIT/IME, Joinville, Brazil, 159 pp (in Portuguese).

Domingues R. B., Anselmo T.P., Barbosa A.B., et al. 2011. Light as a driver of phytoplankton growth and production in the freshwater tidal zone of a turbid estuary. Est. Coast. Shelf Sci. 91: 526-535. http://dx.doi.org/10.1016/j.ecss.2010.12.008

Edler L., Elbrachter M. 2010. The Utermohl method for quantitative phytoplankton analysis. In: Karlson B., Cusack C., Bresnan E. (eds), Microscopic and molecular methods for quantitative phytoplankton analysis. Intergovernmental Oceanographic Commission of UNESCO, Paris, pp. 13-20.

Escobedo J.F., Gomes E.N., Oliveira A.R., et al. 2011. Ratios of UV, PAR and NIR components to global solar radiation measured at Botucatu site in Brazil. Renewable Energy 36: 169-178. http://dx.doi.org/10.1016/j.renene.2010.06.018

FATMA - Fundação do Meio Ambiente de Santa Catarina. 2002. Atlas ambiental da região de Joinville: complexo hídrico da Baía da Babitonga. FATMA/GTZ, Florianópolis, Brazil, 139 pp (in Portuguese).

Fujiki H., Suganuma M. 2009. Carcinogenic aspects of protein phosphatase 1 and 2A inhibitors. Prog. Mol. Subcell. Biol. 46: $221-254$. http://dx.doi.org/10.1007/978-3-540-87895-7 8

Fujita C.C., Odebrecht C. 2007. Short term variability of chlorophyll- $a$ and phytoplankton composition in a shallow area of the Patos Lagoon estuary (southern Brazil). Atlântica, Rio Grande 29: 93-106

Glé C., Del Amo Y., Sautour B., et al. 2008. Variability of nutrients and phytoplankton primary production in a shallow macrotidal coastal ecosystem (Arcachon Bay, France). Est. Coast. Shelf Sci. 76: 642-656. http://dx.doi.org/10.1016/j.ecss.2007.07.043

Grasshoff K., Ehrhardt M., Kremling K. 1983. Methods of Seawater Analysis. 2nd ed. Verlag Chemie, Weinheim, 419 pp.

Holmes W.R. 1970. The Secchi disk in turbid coastal waters. Limnol. Oceanogr. 15: 688-694. http://dx.doi.org/10.4319/1o.1970.15.5.0688

Hoppenrath M., Elbrachter M., Drebes G. 2009. Marine Phytoplankton. Senckenberg Gesellschaft fur Naturforschung, Frank- 
furt am Main, Germany, 264pp.

IBAMA - Instituto Brasileiro do Meio Ambiente e Recursos Renováveis. 1998. Proteção e Controle de Ecossistemas Brasileiros: Manguezal da Baía da Babitonga. Coleção Meio Ambiente, Brasília, Brazil, 145 pp (in Portuguese).

IBGE - Instituto Brasileiro de Geografia e Estatística. Censo Demográfico de 2010. Available at: http://censo2010.ibge.gov.br. Accessed on March 3rd 2015.

Iriarte A., Madariaga I., Diez-Garagarza F., et al. 1996. Primary plankton production, respiration and nitrification in a shallow temperate estuary during summer. J. Exp. Mar. Biol. Ecol. 208: 127-151. http://dx.doi.org/10.1016/S0022-0981(96)02672-X

Ishikawa A., Nishitani G., Kim Y.O., et al. 2014. Relationship between occurrence of the toxic dinoflagellate Dinophysis acuminata and ciliate Mesodinium rubrum in the coastal water of Japan. Abstract Book of the 16th International Conference on Harmful Algae. ISSHA, Wellington, New Zealand, 195 pp.

Jouenne F., Lefebvre S., Véron B., et al. 2005. Biological and physicochemical factors controlling short-term variability in phytoplankton primary production and photosynthetic parameters in a macrotidal ecosystem (eastern English Channel). Est. Coast. Shelf Sci. 65: 421-439. http://dx.doi.org/10.1016/j.ecss.2005.05.023

Kemp W.M., Sampou P.A., Garber J., et al. 1992. Seasonal depletion of oxygen from bottom waters of Chesapeake Bay, roles of benthic and planktonic respiration and physical exchange processes. Mar. Ecol. Prog. Ser. 85: 137-152. http://dx.doi.org/10.3354/meps085137

Kimmerer W.J., Parker A.E., Lidstrom U.E., et al. 2012. Short-term and interannual variability in primary production in the low-salinity zone of the San Francisco Estuary. Estuar. Coast. 35: 913-929. http://dx.doi.org/10.1007/s12237-012-9482-2

Lalli C.M., Parsons T.R. 1997. Biological oceanography: an introduction. 2nd ed. Butterworth-Heinemann, Oxford, 324 pp.

Mafra L.L.Jr., Fernandes L.F., Proença L.A.O. 2006. Harmful algae and toxins in Paranaguá Bay, Brazil: Bases for monitoring. Braz. J. Oceanogr. 54: 107-121.

Mafra L.L.Jr., Tavares C.P.S., Schramm M.A. 2014. Diarrheic toxins in field-sampled and cultivated Dinophysis spp. cells from southern Brazil. J. Appl. Phycol. 26: 1727-1739. http://dx.doi.org/10.1007/s10811-013-0219-9

Maier G., Glegg G.A., Tappin A.D., et al. 2012. A high resolution temporal study of phytoplankton bloom dynamics in the eutrophic Taw Estuary (SW England). Sci. Total Environ. 434: 228-239. http://dx.doi.org/10.1016/j.scitotenv.2011.08.044

Malone T., Conley D., Glibert P., et al. 1996. Scales of nutrient limited phytoplankton productivity: the Chesapeake Bay example. Estuaries 19: 371-385. http://dx.doi.org/10.2307/1352457

Morel A., Smith R.C. 1974. Relation between total quanta and total energy for aquatic photosynthesis. Limnol. Oceanogr. 19: 591-600. http://dx.doi.org/10.4319/10.1974.19.4.0591

Morrisey D.J., Underwood A.J., Stark J.S., et al. 1994. Temporal variation in concentrations of heavy-metals in marine sediments. Estuar. Coast. Shelf Sci. 38: 271-282. http://dx.doi.org/10.1006/ecss.1994.1018

Mortazavi B., Iverson R., Landing W., et al. 2000. Control of phytoplankton production and biomass in a river-dominated estuary: Apalachicola Bay, Florida, USA. Mar. Ecol. Prog. Ser. 198: $19-31$ http://dx.doi.org/10.3354/meps198019

Parizzi R.A., Souza-Conceição J.M., Lorenzi L., et al. 2013. Variação sazonal do fitoplâncton e parâmetros ambientais no canal do rio Palmital, Baía da Babitonga, sul do Brasil. Ciência \& Natura. 35: 41-53.
Pianca C., Mazzini P.L.F., Siegle E. 2010. Brazilian offshore wave climate based on NWW3 reanalysis. Braz. J. Oceanogr. 58: 53-70. http://dx.doi.org/10.1590/S1679-87592010000100006

Proenca L.A.O., Schramm M.A., Tamanaha M.S., et al. 2007. Diarrhoetic shellfish poisoning (DSP) outbreak in subtropical southwest Atlantic. Harmful Algae News 33: 19-20.

Proença L.A.O., Fonseca R.S., Pinto T.O. 2011. Microalgas em área de cultivo do litoral de Santa Catarina. Ed. Rima, São Carlos, Brazil, 90 pp. (in Portuguese)

R Development Core Team. 2012. R: A language and environment for statistical computing. R Foundation for Statistical Computing, Austria. Available at: http://www.R-project.org/.

Reguera B., Riobó P., Rodríguez F., et al. 2014. Dinophysis Toxins: Causative organisms, distribution and fate in shellfish. Mar. Drugs 12: 394-461. http://dx.doi.org/10.3390/md12010394

Sandrini-Neto L., Camargo M.G. 2010. The R Development Core Team. General ANOVA Design (GAD): Analysis of variance from general principles. R package version 1.0.

Schettini C.A.F., Carvalho J.L.B. 1999. Caracterização hidrodinâmica do estuário do Rio Cubatão, Joinville. Notas Téc. Facimar. 3: 87-97.

Shikata T., Nagasoe S., Matsubara T., et al. 2008. Factors influencing the initiation of blooms of the raphidophyte Heterosigma akashiwo and the diatom Skeletonema costatum in a port in Japan. Limnol. Oceanogr. 53: 2503-2518. http://dx.doi.org/10.4319/10.2008.53.6.2503

Song X., Huang L., Zhang J., et al. 2004. Variation of phytoplankton biomass and primary production in Daya Bay during spring and summer. Mar. Pollut. Bull. 49: 1036-1044. http://dx.doi.org/10.1016/j.marpolbul.2004.07.008

Steidinger K.A., Jangen K. 1997. Dinoflagellates. In: Tomas C.R. (eds), Identifying marine diatoms and dinoflagellates. Academic Press, Florida, pp. 387-570. http://dx.doi.org/10.1016/b978-012693018-4/50005-7

Strickland J.D.H., Parsons T.R. 1972. A practical handbook of seawater analysis. 2nd ed. Fisheries Research Board of Canada, Ottawa, pp. 167-311.

Tanaka T., Fujita N., Taniguchi A. 1997. Predator-prey eddy in heterotrophic nanoflagellate-bactéria relationships in a coastal marine environment: a new scheme for predator-prey associations. Aquat. Microb. Ecol. 13: 249-256. http://dx.doi.org/10.3354/ame013249

Tibiriçá C.E.J.A., Fernandes L.F., Mafra L.L.Jr. 2015. Seasonal and spatial patterns of toxigenic species of Dinophysis and Pseudonitzschia in a subtropical Brazilian estuary. Braz. J. Oceanogr. 63: 17-32. http://dx.doi.org/10.1590/S1679-87592015071906301

Tomas R.C. 1997. Identifying marine diatoms and dinoflagellates. Academic Press. Florida, 584 pp.

Truccolo E.C., Schettini C.A.F. 1999. Marés astronômicas na baía da Babitonga, SC. Braz. J. Aquat. Sci. Tech. 3: 57-66. http://dx.doi.org/10.14210/bjast.v3n1.p57-66

Underwood A.J. 1997. Experiments in ecology: their logical design and interpretation using analysis of variance. Cambridge University Press, Cambridge, 504 pp.

Valdiglesias V., Prego-Faraldo M.V., Pásaro E., et al. 2013. Okadaic Acid: More than a Diarrheic Toxin. Mar. Drugs 11: 4328-4349. http://dx.doi.org/10.3390/md11114328

Villar C.C., Spach H.L., Santos L.O. 2011. Fish fauna of Baía da Babitonga (southern Brazil), with remarks on species abundance, ontogenic stage and conservation status. Zootaxa 2734: 40-52.

Yasumoto T., Murata M., Oshima Y., et al. 1985. Diarrhetic shellfish toxins. Tetrahedron 41: 1019-1025. http://dx.doi.org/10.1016/S0040-4020(01)96469-5 